\section{Approaching scientific issues}

While the Ford administration has been setting up the White House Office of Science and Technology Policy (see page 184), Jimmy Carter's campaign organisation has been establishing links with prominent members of the scientific community. Colin Norman reports

ThE campaign between Gerald Ford and Jimmy Carter for President of the United States officially kicked off last wcek with a round of speeches from the two candidates and their VicePresidential choices. Nobody said anything about science, but then nobody really expects scientific issues to play much of a role in this campaign. "Science", as one adviser to the Carter campaign pointed out, "is not exactly the most burning issue in the public mind". Moreover, there's little discernible difference between Republican and Democratic policies for research and development.

But that doesn't mean scientists will play no part in the campaign. Far from it. In fact, it has become something of a tradition for large number of scientists and engineers to shed their usual non-partisan roles and enter the fray on behalf of one candidate or another, and this year will be no different. An extra facet in this campaign, however, is that the Carter organisation has been actively secking advice from a diverse array of scientists, and that advice has been flowing in quite freely.

It is coming from a very loosely knit science policy task force, whose activities are coordinated by Lewis Branscomb, chief scientist for IBM, former director of the National Bureau of Standards and a well respected figure in science policy circles. Other members of the task force include such equally prominent figures as Harold Brown, President of California Institute of Technology, Harvey Brooks, Professor of Technology and Public Policy at Harvard, David Baltimore, a Nobel Prizewinner from MIT, and George Low, President of Renssellaer Polytechnic Institute.

The science policy task force mirrors similar units advising Carter on a vast range of other issues. It is a very informal, ad hoc arrangement involving members who rarely, if ever meet. Instead, they draft policy papers which are sent to the Carter campaign headquarters, to be used as Carter's staff sees fit in drawing up position statements and speeches. As one task force member noted last week, "we haven't exactly got much power in formulating the policies". This conforms with Carter's well-established approach of seeking opinions from a diverse array of individuals before enunciating his own positions. In foreign policy matters, for example, his advisers include people whose perspectives differ so widely that they must be offering all sorts of conflicting advice which the Carter campaign organisers are filtering and stitching together.

Branscomb said last week that he first became acquainted with Carter late last year, and that he was "impressed with (Carter's) intelligence and approach to scientific issues". Branscomb said that he personally favoured Carter's nomination as the Democratic candidate, and agreed to head the science policy task force when Carter approached him. A measure of the generally non-partisan nature of science policy here is that Branscomb was also a member of a committee advising the Ford administration on an agenda for the new White House Office of Science and Technology Policy (OSTP).

Branscomb has repeatedly emphasised the informal nature of the task force, and its broad membership. Many people, he said, are simply being asked for their views on issues, and their involvement carries no implication that they would necessarily endorse Carter's candidacy. "We are trying to make a contribution to good government," he told Nature, and added that the task force is "trying to avoid being an elitist, exclusive club with an inside track".

With Carter already commanding a formidable lead in the public opinion polls, it's clear that the task force is looking beyond November, attempting to lay the groundwork for the first few months of a Carter Administration. In that regard, there has been some speculation that if Carter is elected he will ask Branscomb to be his science adviser and the Director of OSTP. Asked last week whether he would accept such an offer if it is made, Branscomb said the possibility has never been discussed with the Carter organisation, and that he prefers to cross that bridge if he comes to it.

In spite of all the advice flowing into the Carter camp on science policy, so far there is little major difference between the two parties on scientic matters. As far as the party platforms are concerned, for example, though the Republicans devote a few paragraphs to science and technology, the wording is not at all controversial, and could easily have been part of the Democratic manifesto.

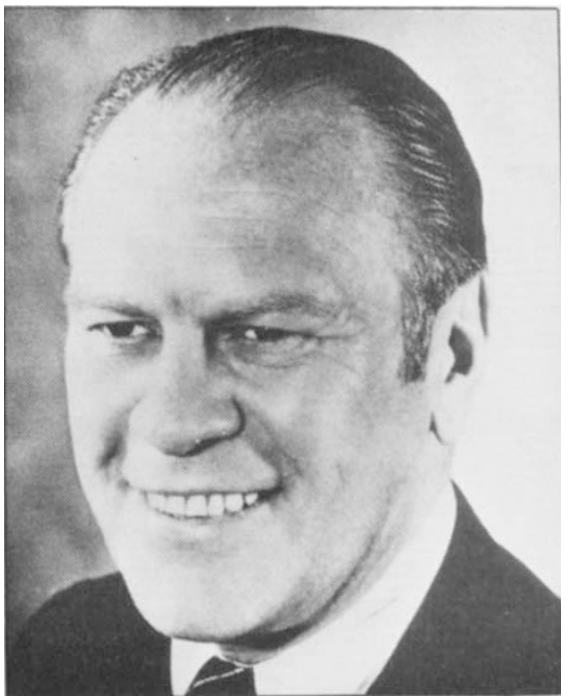

Ford, disastrous

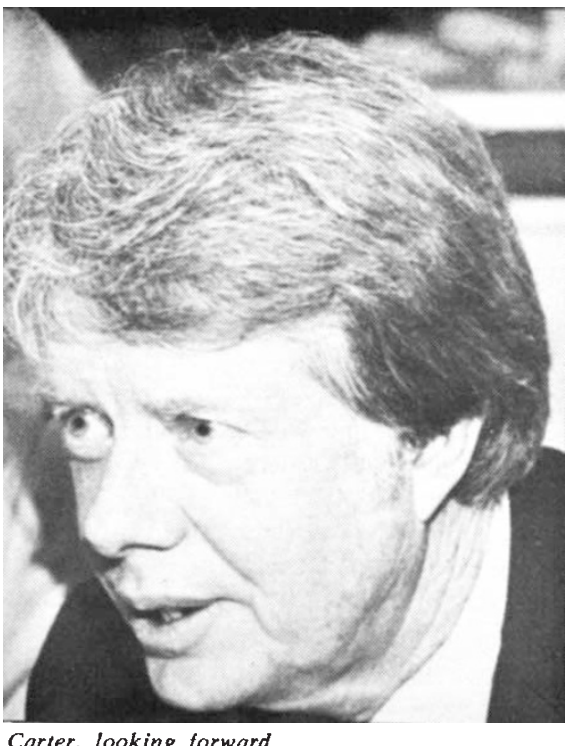

Carter, looking forward

The Republican document states, for example, that "every aspect of our domestic economy and well-being, our international competitive position, and national security is related to our past and present leadership in basic and applied research and the development of our technology. But there can be no complacency about our continued commitment to maintain this leadership position". The Democratic platform simply makes no reference to such matters.

Some differences are, however, beginning to emerge between the two candidates on energy and environmental matters, which have some bearing on research and development.

In a speech before the National Press Club last year, for example, Carter attacked "President Ford's disastrous energy policy", which he described as the "Ford/oil industry energy policy", and claimed that it would eventually lead to higher energy 
prices and greater reliance on oil imports. He said he was looking forward to the opportunity to formulate his own energy policy, in an atmosphere devoid of crisis. Though he hasn't been too specific about his proposals, Carter has since suggested several times that he wants to see more emphasis on conservation, more spending on solar energy, and more reliance on coal. He has also attacked the Ford Administration's plans to push development of a synthetic fuels industry.

The chief difference between the
Carter and Ford energy policies lies in the area of nuclear power. In a statement made to a United Nations conference last May, Carter suggested that dependence on nuclear power should be held to the minimum necessary, and he has said that he would reassess the priority being given to the liquid metal fast breeder reactor-the most expensive single energy research and development project supported by the Ford administration. He has, however, stopped short of calling for a moratorium on nuclear power, and he refused to support the California initiative calling for a virtual halt in the development of nuclear power there. (The initiative was defeated in a state-wide referendum last June.)

As election day approaches, science and technology are unlikely to figure very prominently, simply because they do not figure very prominently among the issues about which people are concerned.

If that is a source of encouragement for scientists, it is largely because of the prestige they enjoy.
AfTER a series of unexpected and often bizarre delays, the newly-recreated White House Office of Science and Technology Policy (OSTP) is finally getting down to business, four months after it was legislated into existence and-if the opinion polls are to be believed-only a few weeks before the Ford administration is scheduled to make its political exit. Even though the administration's days may be numbered in double figures, however, OSTP is being established as if its working arrangements will endure well beyond next January's Presidential inauguration.

H. Guyford Stever, who heads the office and who also holds the title of Science Adviser to the President, said in an interview last week, "I'm not expecting a change of administration. And neither is the President". Accordingly, he is busy recruiting staff, hiring consultants and establishing committees, which means that Jimmy Canter, if he is elected, will inherit a functioning science policy office and some top-level committees whose members would be difficult to replace.

Although legislation establishing the office was signed into law by President Ford on May 11, after taking more than a year to pass through Congress, the OSTP's debut was delayed by an unexpected dispute over the appointment of a director. It had long been rumoured that Ford would nominate Simon Ramo, head of the giant aerospace and defence consortium TRW, as his science adviser and director of OSTP. But the nomination was never made, apparently because Senator Kennedy's office insisted that Ramo would have to divest his holdings in TRW before the Senate would confirm his appointment. Ramo decided that, since the polls all pointed to a resounding Ford defeat in November, it wasn't worth the price to be a science adviser for only a few months. Attention then turned to Guy Stever.

An aerospace engineer and former President of Carnegie-Mellon University, Stever has been Director of the National Science Foundation (NSF) since 1972 and part-time White House Science Adviser since mid1973, when Mr Nixon scrapped the old Office of Science and Technology and consigned some of its functions to the NSF. Stever would therefore seem a logical choice for the full-time post of Presidential Science Adviser. But, when news of his impending nomination filtered out, four rightwing Republican Senators warned Ford that they would oppose the appointment. Led by Senator Jesse

\section{Man at the top}

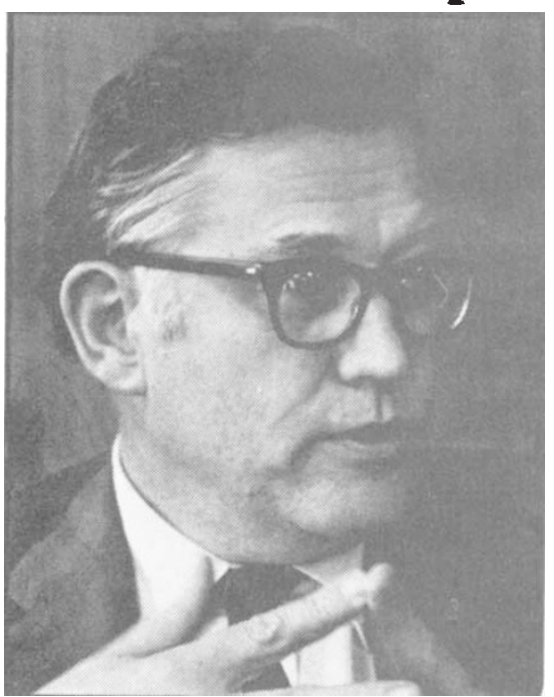

H. Guyford Stever

Helms, they issued a statement critioising Stever's stewardship of the NSF, resurrecting many of the disputes which have swirled around the NSF's education programmes for the past year.

The opposition surfaced while Ford was locked in his neck-and-neck with Ronald Reagan for the Republican nomination. Stever, mindful of the fact that Ford was trying to steer clear of fights with the party's right wing, suggested that his nomination be reconsidered and the matter was put on the back burner for nine weeks. Then, when Ford had the nomination virtually locked up, Stever's nomination was sent to the Senate early in August and swiftly approved with only token opposition.

Stever said last week that he agreed to take on the assignment with the understanding that he wouldn't remain long after January, no matter which administration takes office.

The legislation establishing OSTP also sets up a top-level advisory committee, consisting of between 8 and 14 people drawn from a variety of fields, which will conduct a two-year investigation of federal science support and priorities. One of Stever's first acts was to recommend that Ramo be appointed chairman of that committee, a suggestion which Ford promptly accepted. The other members will be appointed later this month. (Ramo's appointment, incidentally, will present an interesting situation if Carter becomes President, for Ramo was a co-chairman in 1972 of a committee of scientists and engineers supporting the candidacy of Richard Nixon.)

Stever has begun to staff the office with people drawn from NSF's science policy office and a few individuals on secondment from other government agencies. In addition, he has appointed two senior policy consultants, William Nierenberg, Director of the Scripps Institution of Oceanography, and Donald Kennedy, Chairman of the Program in Human Biology at Stanford University. Both will devote half their time to OSTP, assisting in the development of policy studies on biological and environmental issues. Other consultants, Stever indicated, will be called upon as needed.

Asked last week what he considers as OSTP's chief goal, Stever said, "some scientists think that the goal should be to increase the support for science, but they are mistaken. The important thing is to establish an easy relationship at the top level of our government for the scientific community to have an input" into national policy. Colin Norman 